\title{
The effect of vitamin D on cognitive functions in young female patients: a prospective controlled study using the Montreal Cognitive Assessment
}

\author{
O efeito da vitamina $D$ nas funções cognitivas em pacientes jovens do sexo feminino: um \\ estudo prospectivo controlado usando a avaliação cognitiva de Montreal
}

Ozlem Balbaloglu', Nermin Tanık

\begin{abstract}
Aim: Our aim was to determine whether there is a relationship between vitamin $\mathrm{D}[25(\mathrm{OH}) \mathrm{D}]$ and cognitive functioning in women with low 25(OH)D levels. Methods: Ninety female patients, 25-45 years of age, who attended our outpatient clinic and had 25(OH)D levels $<30 \mathrm{ng} /$ $\mathrm{mL}$, were included. The Montreal Cognitive Assessment (MoCA) scale was used to determine cognitive functioning; the scale is divided into seven subgroups. Patients were divided into three subgroups according to their $25(\mathrm{OH}) \mathrm{D}$ levels. After a three-month period of $25(\mathrm{OH})$ $D$ replacement, the patients underwent a re-evaluation using the MoCA scale. Results: The total MoCA score before treatment was significantly different from the score after treatment $(p<0.05)$. Language and delayed recall functions were significantly different before and after treatment $(p<0.05)$. Conclusion: Vitamin $D$ levels were related to cognitive functioning in our study group.
\end{abstract}

Keywords: Vitamin D; cognition; Montreal cognitive assessment.

\section{RESUMO}

Objetivo: Nosso objetivo foi determinar se existe uma relação entre a vitamina $D[25(\mathrm{OH}) \mathrm{D}]$ e o funcionamento cognitivo em mulheres com baixos níveis de 25(OH)D. Métodos: Noventa pacientes do sexo feminino (25-45 anos de idade) que se apresentaram ao nosso ambulatório e tinham níveis de $25(\mathrm{OH}) \mathrm{D}<30 \mathrm{ng} / \mathrm{mL}$ foram incluídas. A escala de avaliação cognitiva de Montreal (MoCA) foi usada para determinar o funcionamento cognitivo; a escala é dividida em sete subgrupos. As pacientes foram divididas em três subgrupos de acordo com seus níveis de 25(OH)D. Após um período de três meses de reposição de 25(OH)D, as pacientes foram submetidas a uma reavaliação de acordo com a escala MoCA. Resultados: 0 escore total da MoCA antes do tratamento foi significativamente diferente do escore após o tratamento ( $\mathrm{p}$ $<0,05)$. As funções de idioma e recordação atrasada foram mais significativamente diferentes entre antes e depois do tratamento $(p<0,05)$. Conclusão: $O$ nivel de vitamina D foi relacionado ao funcionamento cognitivo em nosso grupo de estudo.

Palavras-chave: Vitamina D; cognição; Testes de estado mental e demência.

Vitamin D (25-hydroxy vitamin D [25(OH)D] is a steroid hormone with a variety of physiological roles. In addition to its well-known role in calcium homeostasis, several more-recent publications have indicated that vitamin D deficiency can lead to deficits in neurocognitive functioning ${ }^{1}$. The relationship between vitamin $\mathrm{D}$ and central nervous system functioning has been investigated for many years. It is known that the enzyme responsible for synthesizing the vitamin $\mathrm{D}$ receptor and the active form of $25(\mathrm{OH}) \mathrm{D}$ are present in the central nervous system². Moreover, 25(OH)D increases gamma glutamyl transpeptidase and glutathione, and glutathione is a natural antioxidant that protects the integrity of the neurotransmitter pathway critical for oligodendrocytes and mental processes ${ }^{3}$. The 25(OH)D regulates neuronal calcium homeostasis and protects neurons from excessive calcium intake ${ }^{4}$. A reduction in 25(OH)D concentration has been associated with a decline in cognitive functioning, as well as impaired cognitive functions such as memory, orientation $^{5,6,7,8}$, and executive functions ${ }^{9,10}$ in patients with dementia and Alzheimer's disease ${ }^{11}$. 
Previous studies have generally been conducted in groups of individuals of an older age; data on younger individuals are limited, and subgroups have not been precisely evaluated ${ }^{9,12,13,14,15}$. The main question about $25(\mathrm{OH}) \mathrm{D}$ and cognitive dysfunction is whether a vitamin $\mathrm{D}$ deficiency impairs cognitive functions. This study elucidated the causal contribution of 25(OH)D to outcomes related to cognitive functioning and determined whether 25(OH)D replacement therapy affects functioning in these domains. We prospectively investigated whether there is a correlation between $25(\mathrm{OH}) \mathrm{D}$ and cognitive functioning in young female patients with a $25(\mathrm{OH})$ $\mathrm{D}$ deficiency, and whether there is a difference in cognitive functioning after $25(\mathrm{OH}) \mathrm{D}$ replacement.

\section{METHODS}

Female patients (aged 25-45 years of age) who were admitted to the physical therapy and rehabilitation outpatient clinic between May 2017 and September 2017, who had a low 25(OH)D < $30 \mathrm{ng} / \mathrm{ml}$, did not complain of cognitive dysfunction, and scored $<10$ points on the Beck Depression Inventory, were included in the study. The demographic data, age, and educational level of the patients were recorded. Calcium, phosphorus, magnesium, 25(OH)D, and parathyroid hormone values were measured. The patients were divided into three groups according to their 25(OH)D level: < $10 \mathrm{ng} /$ $\mathrm{mL}$ (group 1, $\mathrm{n}=30$ ), $10-20 \mathrm{ng} / \mathrm{mL}$ (group 2, $\mathrm{n}=30$ ), and 20-29 $\mathrm{ng} / \mathrm{mL}$ (group 3, $\mathrm{n}=30$ ). The Montreal Cognitive Assessment (MoCA) scale was used to assess cognitive functioning. The scale is divided into seven subscales. The participants were treated according to their low 25(OH)D levels ${ }^{16}$. We treated all adults who were vitamin $D$ deficient with 50,000 IU of vitamin D, once a week for eight weeks, to achieve a blood level of $25(\mathrm{OH}) \mathrm{D}$ above $30 \mathrm{ng} / \mathrm{ml}$, followed by maintenance therapy of 1,500-2,000 IU/d. The participants were re-evaluated three months later using the MoCA scale.

\section{Exclusion criteria}

We excluded patients with autoimmune and chronic inflammatory diseases (rheumatoid arthritis and ankylosing spondylitis etc), chronic systemic diseases (chronic renal failure and liver disease etc), known malabsorption (celiac sprue or radiation enteritis etc), active infection, cancer, thyroid/parathyroid disease, low vitamin B12 level, history of a neurological disease, psychiatric disorder history (depression, anxiety, psychosis, schizophrenia, bipolar disorder etc), glucocorticoid use, hormone replacement, antiepileptic drug use, cerebrovascular accident, central nervous system tumors, head trauma, multiple sclerosis, epilepsy, movement disorders or migraine treatment, current or recent history of dependence on alcohol or illicit substances, intellectual disability, sleeping problems, pregnancy, and fibromyalgia.
This study was approved by the Ethics Review Board of Bozok University, Faculty of Medicine (no: 2017/01-05/30). Written informed consent was obtained from each participant. The study was conducted in accordance with the principles of the Declaration of Helsinki.

\section{Serum 25(OH)D measurement}

Serum 25(OH)D levels were measured with the Architect i2000 (Abbott, Diagnostics, Wiesbaden, Germany) operating with the use of chemiluminescent microparticle immunoassay technology. The linearity of assay was $3.4-155.9 \mathrm{ng} /$ $\mathrm{ml}$. The manufacturer reports an intra-assay precision of $2.3 \%, 2.1 \%, 2.8 \%$ and a total precision of $3 \%, 3.1 \%, 4.1 \%$ for values 20, 40, $78.3 \mathrm{ng} 7 \mathrm{dl}$ (respectively). Serum 25(OH)D levels $<10 \mathrm{ng} / \mathrm{ml}$ were considered a severe deficiency, 10-20 ng/ $\mathrm{ml}$ was considered a deficiency, $21-29 \mathrm{ng} / \mathrm{ml}$ was considered an insufficiency, and $\geq 30 \mathrm{ng} / \mathrm{ml}$ was considered sufficient. Measurements of serum 25(OH)D levels are considered the best indicator to assess the overall vitamin $\mathrm{D}$ profile ${ }^{16}$.

\section{Montreal Cognitive Assessment}

The MoCA was developed as a rapid screening test to assess mild cognitive impairment ${ }^{17}$. This test evaluates seven different cognitive functions, including attention and concentration, executive functions, delayed recall, language, visuospatial construction, abstract (conceptual) thinking, and orientation to time and place. The MoCA takes about 10 minutes to complete. The highest total score on the test is 30 points, and $\geq 21$ points is considered normal. A Turkish validity and reliability study has been conducted ${ }^{18}$.

Montreal Cognitive Assessment assesses the following:

1) The short-term memory recall task (5 points) involves two learning trials of five nouns and delayed recall after approximately five minutes;

2) Visuospatial abilities are assessed using a clock-drawing task (3 points) and a three-dimensional cube copy (1 point);

3) Multiple aspects of executive functions are assessed using an alternation task adapted from the Trail Making B task (1 point), and a phonemic fluency task (1 point);

4) Two-item verbal abstraction task (2 points);

5) Attention, concentration, and working memory are evaluated using a sustained attention task (target detection using tapping; 1 point), a serial subtraction task (3 points), and digits forward and backward (1 point each);

6) Language is assessed using a three-item confrontation naming task with low-familiarity animals (lion, camel, rhinoceros; 3 points), repetition of two syntactically complex sentences ( 2 points), and the aforementioned fluency task;

7) Orientation to time and place (6 points).

\section{Statistics}

The distribution of MoCA scores was not homogeneous, so the differences between the groups were assessed by the nonparametric Mann-Whitney U and chi-square tests. The 
results are reported as mean \pm standard deviation or as percentages. Differences among the groups were tested with analysis of variance. A post-hoc test was used to determine from which group the difference originated. The paired sample t-test was used for each group in the before-treatment and after-treatment comparisons. A p-value $<0.05$ was accepted as significant. The statistical analyses were performed using SPSS 20.0 software (SPSS Inc., Chicago, IL, USA).

\section{RESULTS}

In total, 90 female patients with the mean age of 37 years (min: 29 - max: 44) (group 1), 38 years (min: 25 - max: 45) (group 2), 37 years (min: 26 - max: 45) (group 3) were included.

No significant differences in the demographic data or blood levels, except 25(OH)D levels, were observed among the groups $(\mathrm{p}>0.05)$ (Table 1$)$. The 25(OH)D levels of each group are shown in Table 2. The mean before and after treatment MoCA values of the groups were within the normal limits in separate and total points (Table 3).

A significant difference was found when the before treatment and after treatment MoCA total scores of the three groups were compared ( $p<0.05, p<0.001$, respectively) (Table $3)$. No differences were observed among the groups in terms of attention, conceptual thinking, executive function, or orientation before and after treatment $(p>0.05)$. Language and delayed recall functions were significantly different before and after treatment $(\mathrm{p}<0.05)$ (Table 3).
A significant difference was found between group 1 and groups 2 and 3 in the MoCA total score before treatment ( $p<$ 0.05), but no significant difference was observed between the groups after treatment $(\mathrm{p}>0.05)$ (Table 4).

\section{DISCUSSION}

This is the first study, to our knowledge, evaluating the effects of 25(OH)D replacement in adult females in terms of key cognitive measures by MoCA. In our study, the MoCA scores of all participants were within the normal limits. However, we found a significant difference in the total MoCA scores before treatment and after treatment in all three groups and more significantly in language and delayed recall as a subgroup. Some studies ${ }^{11}$ have shown that a low concentration of $25(\mathrm{OH}) \mathrm{D}$ could be effective in diseases, such as dementia and Alzheimer's disease at later ages, as well as in cognitive dysfunction, such as memory and orientation $^{5,8}$ and executive dysfunction ${ }^{9,10}$, but it is not exactly clear whether the concentration of $25(\mathrm{OH}) \mathrm{D}$ actually alters cognitive functioning.

Jorde et al. ${ }^{13}$ demonstrated an average of $5 \%$ better performance on tests in participants older than 65 years, but did not find a correlation between 25(OH)D levels and cognitive function test scores in individuals younger than 65 years of age (mean age: 57 years). They divided the patients into four groups according to their 25(OH)D level, and did not find any difference between the groups. A population comprising male and female participants,

Table 1. Demographic properties and laboratory findings of the patient.

\begin{tabular}{|c|c|c|c|c|c|}
\hline Variable & $\begin{array}{c}\text { Group } 1 \\
\text { (vitamin } \mathrm{D}<10 \mathrm{ng} / \mathrm{mL} \text { ) }\end{array}$ & $\begin{array}{c}\text { Group } 2 \\
\text { (vitamin } \mathrm{D}=10-<20 \mathrm{ng} / \mathrm{mL} \text { ) }\end{array}$ & $\begin{array}{c}\text { Group } 3 \\
\text { (vitamin } \mathrm{D}=20-<29 \mathrm{ng} / \mathrm{mL} \text { ) }\end{array}$ & Total & $p$-value \\
\hline & $n=30$ & $n=30$ & $\mathrm{n}=30$ & $\mathrm{n}=90$ & \\
\hline Age & $37.07 \pm 4.5$ & $38.13 \pm 5.9$ & $36.83 \pm 5.4$ & $37.26 \pm 5.3$ & $0.73^{F}$ \\
\hline \multicolumn{6}{|l|}{ Education n (\%) } \\
\hline Middle school & $17(43.6)$ & $11(28.2)$ & $11(28.2)$ & $39(100)$ & \\
\hline High school & $9(27.3)$ & $12(36.4)$ & $12(36.4)$ & $33(100)$ & $0.49^{\mathrm{csT}}$ \\
\hline University & $4(22.2)$ & $7(38.9)$ & $7(38.9)$ & 18(100) & \\
\hline $25(\mathrm{OH}) \mathrm{D}(\mathrm{ng} / \mathrm{mL})$ & $5.95 \pm 1.9$ & $15.16 \pm 2.7$ & $22.70 \pm 1.9$ & & $0.02 *$ \\
\hline PTH (pg/mL) & $90.43 \pm 11.8$ & $72.29 \pm 20.3$ & $71.94 \pm 18.9$ & & 0.45 \\
\hline $\mathrm{Ca}(\mathrm{mg} / \mathrm{dL})$ & $9.37 \pm 0.4$ & $9.53 \pm 0.4$ & $9.20 \pm 1.8$ & & 0.49 \\
\hline Phosphorus (mg/dL) & $2.21 \pm 0.5$ & $2.12 \pm 0.4$ & $2.25 \pm 0.4$ & & 0.79 \\
\hline $\operatorname{ALP}(U / L)$ & $63.90 \pm 15.4$ & $68.07 \pm 15.5$ & $65.30 \pm 19$ & & 0.50 \\
\hline
\end{tabular}

Data are expressed as mean \pm standard deviation, or the number (percentage) of cases; F: ANOVA: analysis of variance; CST: Chi-square test; *Statistical significance: $p<0.05$; ALP:Alkaline phosphatase; PTH: Parathyroid hormone; Normal ranges: calcium; 8.8-10.6 mg/dL, phosphorus; 2.5-4.5 mg/dL, ALP:30-120 U/L, PTH; $12-88 \mathrm{pg} / \mathrm{mL}, 25(\mathrm{OH}) \mathrm{D}>30 \mathrm{ng} / \mathrm{mL}$.

Table 2. Vitamin D levels of each group.

\begin{tabular}{|c|c|c|c|c|}
\hline \multirow{2}{*}{ Vitamin D } & Group 1 & Group 2 & Group 3 & Total \\
\hline & $\mathrm{X} \pm \mathrm{SD}$ & $\mathrm{X} \pm \mathrm{SD}$ & $\mathrm{X} \pm \mathrm{SD}$ & $\mathrm{X} \pm \mathrm{SD}$ \\
\hline Before treatment & $5.95 \pm 1.95$ & $15.16 \pm 2.76$ & $22.98 \pm 1.91$ & $14.69 \pm 7.34$ \\
\hline After treatment & $45.07 \pm 8.37$ & $50.22 \pm 6.55$ & $52.42 \pm 5.50$ & $49.24 \pm 7.50$ \\
\hline Test* & $p<0.001$ & $p<0.001$ & $p<0.001$ & $p<0.001$ \\
\hline
\end{tabular}


nearly half of whom were college graduates, was assessed by the Mini Mental State Examination. Unlike that study, our participants comprised younger age groups, and we found a significant difference in the total scores of all participants, and in the postreplacement MoCA scores of the subgroups.

Dean et al. ${ }^{14}$ divided healthy young subjects with normal 25(OH)D levels (mean ages: case group: 21 years, control group: 22 years) into two groups and provided $25(\mathrm{OH}) \mathrm{D}$ supplementation to one group for six weeks while the other group received a placebo. At the end of six weeks, they did not find a significant change in cognitive functioning between the groups, indicating that $25(\mathrm{OH}) \mathrm{D}$ supplementation had no effect on cognitive function. However, Dean et al. ${ }^{14}$ designed the study with participants with normal 25(OH)D levels. The 25(OH)D levels of the patients who participated in our study were low. The MoCA scores of the participants were within the normal range, but a significant difference was found between the initial values and the post-replacement scores.

Table 3. The means of MoCA scores before and after treatment of groups.

\begin{tabular}{|c|c|c|c|c|}
\hline \multirow{2}{*}{ MoCA Subgroups } & Group 1 & Group 2 & Group 3 & Total MoCA \\
\hline & $\mathrm{X} \pm \mathrm{SD}$ & $\mathrm{X} \pm \mathrm{SD}$ & $\mathrm{X} \pm \mathrm{SD}$ & $\mathrm{X} \pm \mathrm{SD}$ \\
\hline \multicolumn{5}{|l|}{ Visual Structuring } \\
\hline Before treatment & $3.33 \pm 0.75$ & $3.60 \pm 0.67$ & $3.83 \pm 0.37$ & $3.59 \pm 0.65$ \\
\hline After treatment & $3.83 \pm 0.37$ & $4.0 \pm 0.00$ & $3.8 \pm 0.37$ & $3.93 \pm 0.25$ \\
\hline Test* & $p=0.001$ & $p=0.003$ & $p=1.000$ & $p<0.001$ \\
\hline \multicolumn{5}{|l|}{ Language } \\
\hline Before treatment & $4.10 \pm 0.54$ & $4.30 \pm 0.53$ & $4.57 \pm 0.50$ & $4.32 \pm 0.55$ \\
\hline After treatment & $4.33 \pm 0.54$ & $4.50 \pm 0.50$ & $4.73 \pm 0.45$ & $4.52 \pm 0.52$ \\
\hline Test* & $p=0.01$ & $p=0.01$ & $p=0.02$ & $p<0.001$ \\
\hline \multicolumn{5}{|l|}{ Executive Functions } \\
\hline Before treatment & $1.53 \pm 0.62$ & $1.53 \pm 0.50$ & $1.27 \pm 0.64$ & $1.44 \pm 0.60$ \\
\hline After treatment & $1.73 \pm 0.45$ & $1.80 \pm 0.40$ & $1.70 \pm 0.46$ & $1.74 \pm 0.43$ \\
\hline Test* & $p=0.08$ & $p=0.009$ & $p=0.002$ & $p<0.001$ \\
\hline \multicolumn{5}{|c|}{ Time/Place Orientation } \\
\hline Before treatment & $6.0 \pm 0.0$ & $6.0 \pm 0.0$ & $5.97 \pm 0.18$ & $5.99 \pm 0.10$ \\
\hline After treatment & $6.0 \pm 0.0$ & $6.0 \pm 0.0$ & $6.0 \pm 0.0$ & $6.0 \pm 0.0$ \\
\hline Test* & $¥$ & $¥$ & $p=0.32$ & $p=0.32$ \\
\hline \multicolumn{5}{|l|}{ Conceptual Thinking } \\
\hline Before treatment & $1.13 \pm 0.62$ & $1.07 \pm 0.58$ & $1.20 \pm 0.66$ & $1.13 \pm 0.62$ \\
\hline After treatment & $1.20 \pm 0.55$ & $1.20 \pm 0.61$ & $1.40 \pm 0.62$ & $1.27 \pm 0.59$ \\
\hline Test* & $p=0.42$ & $p=0.25$ & $p=0.05$ & $p=0.02$ \\
\hline \multicolumn{5}{|l|}{ Delayed Recall } \\
\hline Before treatment & $3.30 \pm 0.98$ & $3.80 \pm 0.88$ & $4.10 \pm 0.88$ & $3.73 \pm 0.96$ \\
\hline After treatment & $4.53 \pm 0.73$ & $4.50 \pm 0.73$ & $4.57 \pm 0.56$ & $4.53 \pm 0.67$ \\
\hline Test* & $p<0.001$ & $p<0.001$ & $p=0.001$ & $p<0.001$ \\
\hline \multicolumn{5}{|c|}{ Attention, Concentration, Memory } \\
\hline Before treatment & $3.33 \pm 1.18$ & $3.63 \pm 1.42$ & $3.63 \pm 1.27$ & $3.53 \pm 1.29$ \\
\hline After treatment & $3.60 \pm 1.22$ & $3.93 \pm 1.33$ & $3.83 \pm 1.23$ & $3.79 \pm 1.25$ \\
\hline Test* & $p=0.05$ & $p=0.02$ & $p=0.11$ & $p=0.001$ \\
\hline \multicolumn{5}{|l|}{ Total MoCA } \\
\hline Before treatment & $22.50 \pm 1.13$ & $23.90 \pm 1.56$ & $24.40 \pm 1.83$ & $23.60 \pm 1.72$ \\
\hline After treatment & $25.10 \pm 1.47$ & $25.53 \pm 1.52$ & $26.00 \pm 1.62$ & $25.56 \pm 1.55$ \\
\hline Test* & $p<0.001$ & $p<0.001$ & $p<0.001$ & $p<0.001$ \\
\hline
\end{tabular}

Table 4. Significance levels between groups of total MOCA score before treatment and after treatment.

\begin{tabular}{|c|c|c|c|c|c|c|}
\hline \multirow{2}{*}{ MoCA total score } & \multicolumn{3}{|c|}{ MoCA before treatment } & \multicolumn{3}{|c|}{ MoCA after treatment } \\
\hline & Group1 & Group 2 & Group 3 & Group1 & Group 2 & Group 3 \\
\hline \multicolumn{7}{|l|}{ Before treatment } \\
\hline Group 1 & - & $0.002 *$ & $<0.001^{*}$ & & & \\
\hline Group 2 & $0.002^{*}$ & - & 0.42 & & & \\
\hline \multicolumn{7}{|l|}{ After treatment } \\
\hline Group 1 & & & & - & 0.51 & 0.05 \\
\hline Group 2 & & & & 0.51 & - & 0.41 \\
\hline
\end{tabular}


A meta-analysis that included 7,688 participants showed an increased risk of cognitive impairment in those with low vitamin D levels compared to those with normal vitamin D levels (odds ratio 2.39, 95\% confidence interval 1.91-3.00; $p<0.000)^{19}$.

Studies that have assessed subgroups have generally been conducted on groups of individuals of an older age. A study conducted by Miller et al. ${ }^{20}$ found that ethnically-different older adults exhibiting a high prevalence of vitamin D insufficiency or deficiency were associated with a decline in cognitive function domains. Four cognitive domains (episodic memory, semantic memory, visual perception, and executive function) were measured. The cognitive decline rate associated with hypovitaminosis D (insufficiency and deficiency) was strongly associated with Alzheimer's dementia for episodic memory and executive function. In our study, we found a more significant difference in language and delayed memory.

McGrath et al. ${ }^{12}$ divided participants into three groups of adolescents (12-17 years), adults (20-60 years), and an older group (60-90 years) to investigate the correlation between vitamin D levels and cognitive performance. They did not find a correlation between $25(\mathrm{OH}) \mathrm{D}$ levels and cognitive function in the adolescent or adult groups. They found that vitamin $\mathrm{D}$ did not affect cognitive function in the adult age group. In our study, the MoCA scores of all participants were within the normal limits in accordance with the literature. However, there was a significant difference in the MoCA scores after treatment.

A systematic review conducted by Annweiler et al. ${ }^{21}$ showed that vitamin $\mathrm{D}$ deficiency may negatively affect specific cognitive functions, such as episodic memory, which have not been fully investigated. Studies that have evaluated total cognitive performance (Clinical Dementia Rating or Mini Mental State Examination) have reported a significant correlation with a vitamin $\mathrm{D}$ deficiency.

In conclusion, the significant positive correlation between serum 25(OH)D concentrations and cognitive function is controversial when considering age $\mathrm{e}^{5,7,12,13,22}$. Recent evidence has shown that vitamin $\mathrm{D}$ may reduce age-related tau hyperphosphorylation, nitrosative protein damage ${ }^{23}$, formation of $\mathrm{A} \beta$ oligomers. It has been shown that the active $25(\mathrm{OH}) \mathrm{D}$ metabolites rebalance inflammation and promote $\mathrm{A} \beta$ phagocytosis in mononuclear cells of peripheral blood in patients with Alzheimer's disease ${ }^{24,25}$. Despite the limited number of studies, the more intense distribution of the vitamin $\mathrm{D}$ receptor in some regions of the brain suggests that 25(OH)D may affect certain neurotransmitters and cortical functions. Expression of the vitamin D receptor has been identified in the hippocampus and prefrontal cortex areas. These areas are important for learning, memory, and executive control ${ }^{22,25,26,27,28,29}$. In vitro and animal studies have shown that low 25(OH)D increased white matter hyperintensities ${ }^{30,31}$ and ventricular volumes ${ }^{32,33}$. The results of these studies suggest that a low 25(OH)D level alters development of the brain.

Several issues must be considered when evaluating this process. These issues are: 1) whether the pathophysiology of this process is relevant for chronic period or; 2) it occurs if a person is exposed to vitamin D deficiency but for how long time and at what level; 3) whether a decrease in cognitive functions seen at early ages are caused by the same mechanism; iv) whether genetic factors, especially vitamin D receptor gene polymorphisms affect this process. None of these issues are clearly known.

Some limitations of our study should be discussed. The sample size was small, and all of the participants were female. The educational levels of the participants differed. Cognitive function was assessed by the MoCA but other neuropsychiatric tests could have been performed in conjunction with this test. The MoCA is useful for detecting mild cognitive impairment in older ages, but it is unknown whether it is applicable to younger ages. A brief summary of the verbal and delayed recall in the test analyses (subgroups) may not have provided a precise measure of cognitive function. The test was repeated after three months, so the follow-up time was short.

\section{CONCLUSION}

The effect of $25(\mathrm{OH}) \mathrm{D}$ on cognitive function is not fully known in the young-adult population. No correlation was found between the vitamin $\mathrm{D}$ level and cognitive function in young adults compared with older ages in the small number of studies in the literature. However, the subgroups have not been adequately investigated. The $25(\mathrm{OH}) \mathrm{D}$ levels of the patients participating in our study were low and, when evaluated with the MoCA before and after vitamin D replacement, there was a significant difference in the MoCA total scores before treatment and after treatment, especially in the language and delayed recall subgroups. It was difficult to determine how much of this improvement depended on the increase in vitamin D concentration. Prospective, controlled studies with a long-term follow-up are necessary in young adults, including both male and female populations, to reach a definite conclusion.

\section{References}

1. Spiro A, Buttriss JL. Vitamin D: an overview of vitamin D status and intake in Europe. Nutr Bull. 2014 Dec;39(4):322-50. https://doi.org/10.1111/nbu.12108

2. Eyles DW, Smith S, Kinobe R, Hewison M, McGrath JJ. Distribution of the vitamin $\mathrm{D}$ receptor and 1 alpha-hydroxylase in human brain. J Chem Neuroanat. 2005 Jan;29(1):21-30. https://doi.org/10.1016/j.jchemneu.2004.08.006
3. Baas D, Prüfer K, Ittel ME, Kuchler-Bopp S, Labourdette G, Sarliève LL et al. Rat oligodendrocytes express the vitamin $\mathrm{D}(3)$ receptor and respond to 1,25-dihydroxyvitamin D(3). Glia. 2000 Jul;31(1):59-68. https://doi. org/10.1002/(SICI)1098-1136(200007)31:1<59::AID-GLIA60>3.0.CO;2-Y

4. Brewer LD, Thibault V, Chen KC, Langub MC, Landfield PW, Porter NM. Vitamin D hormone confers neuroprotection in parallel 
with downregulation of L-type calcium channel expression in hippocampal neurons. J Neurosci. 2001 Jan;21(1):98-108. https://doi.org/10.1523/JNEUROSCI.21-01-00098.2001

5. Wilkins $\mathrm{CH}$, Sheline YI, Roe CM, Birge SJ, Morris JC. Vitamin $\mathrm{D}$ deficiency is associated with low mood and worse cognitive performance in older adults. Am J Geriatr Psychiatry. 2006 Dec;14(12):1032-40. https://doi.org/10.1097/01.JGP.0000240986.74642.7c

6. Buell JS, Dawson-Hughes B. Vitamin D and neurocognitive dysfunction: preventing “D”ecline? Mol Aspects Med. 2008 Dec;29(6):415-22. https://doi.org/10.1016/j.mam.2008.05.001

7. Przybelski RJ, Binkley NC. Is vitamin D important for preserving cognition? A positive correlation of serum 25-hydroxyvitamin D concentration with cognitive function. Arch Biochem Biophys. 2007 15;460(2):202-5. https://doi.org/10.1016/j.abb.2006.12.018

8. Llewellyn DJ, Langa KM, Lang IA. Serum 25-hydroxyvitamin D concentration and cognitive impairment. J Geriatr Psychiatry Neurol. 2009 Sep;22(3):188-95. https://doi.org/10.1177/0891988708327888

9. Buell JS, Scott TM, Dawson-Hughes B, Dallal GE, Rosenberg IH, Folstein MF et al. Vitamin D is associated with cognitive function in elders receiving home health services. J Gerontol A Biol Sci Med Sci. 2009 Aug;64(8):888-95. https://doi.org/10.1093/gerona/glp032

10. Lee DM, Tajar A, Ulubaev A, Pendleton N, O'Neill TW, O'Connor DB et al. Association between 25-hydroxyvitamin D levels and cognitive performance in middle-aged and older European men. J Neurol Neurosurg Psychiatry. 2009 Jul;80(7):722-9. https://doi.org/10.1136/jnnp.2008.165720

11. Buell JS, Dawson-Hughes B, Scott TM, Weiner DE, Dallal GE, Qui WQ et al. 25-Hydroxyvitamin D, dementia, and cerebrovascular pathology in elders receiving home services. Neurology. 2010 Jan;74(1):18-26. https://doi.org/10.1212/WNL.0b013e3181 beecb7

12. McGrath J, Scragg R, Chant D, Eyles D, Burne T, Obradovic D. No association between serum 25-hydroxyvitamin D3 level and performance on psychometric tests in NHANES III. Neuroepidemiology. 2007;29(1-2):49-54. https://doi.org/10.1159/000108918

13. Jorde R, Mathiesen EB, Rogne S, Wilsgaard T, Kjærgaard M, Grimnes G et al. Vitamin D and cognitive function: the Troms $\varnothing$ Study. J Neurol Sci. 2015 Aug;355(1-2):155-61. https://doi.org/10.1016/j.jns.2015.06.009

14. Dean AJ, Bellgrove MA, Hall T, Phan WM, Eyles DW, Kvaskoff D et al. Effects of vitamin D supplementation on cognitive and emotional functioning in young adults - a randomised controlled trial. PLoS One. 2011;6(11):e25966. https://doi.org/10.1371/journal.pone.0025966

15. Ferreira KS, Oliver GZ, Thomaz DC, Teixeira CT, Foss MP. Cognitive deficits in chronic pain patients, in a brief screening test, are independent of comorbidities and medication use. Arq Neuropsiquiatr. 2016 May;74(5):361-6. https://doi.org/10.1590/0004-282X20160071

16. Holick MF, Binkley NC, Bischoff-Ferrari HA, Gordon CM, Hanley DA, Heaney RP et al. Evaluation, treatment, and prevention of vitamin D deficiency: an Endocrine Society clinical practice guideline. J Clin Endocrinol Metab. $2011 \mathrm{Jul}$;96(7):1911-30. https://doi.org/10.1210/jc.2011-0385

17. Nasreddine ZS, Phillips NA, Bédirian V, Charbonneau S, Whitehead V, Collin I et al. The Montreal Cognitive Assessment, MoCA: a brief screening tool for mild cognitive impairment. J Am Geriatr Soc. 2005 Apr;53(4):695-9. https://doi.org/10.1111/j.1532-5415.2005.53221.x

18. Selekler K, Cangöz B, Uluç S. Montreal Bilișsel Değerlendirme Ölçeği (MOBiD)'nin hafif bilișsel bozukluk ve Alzheimer hastalarını ayırt edebilme gücünün incelenmesi. Turk Geriatri Derg. 2010;13:166-71.

19. Etgen T, Sander D, Bickel H, Sander K, Förstl H. Vitamin D deficiency, cognitive impairment and dementia: a systematic review and meta-analysis. Dement Geriatr Cogn Disord. 2012;33(5):297-305. https://doi.org/10.1159/000339702
20. Miller JW, Harvey DJ, Beckett LA, Green R, Farias ST, Reed BR et al. Vitamin D Status and Rates of Cognitive Decline in a Multiethnic Cohort of Older Adults. JAMA Neurol. 2015 Nov;72(11):1295-303. https://doi.org/10.1001/jamaneurol.2015.2115

21. Annweiler C, Allali G, Allain P, Bridenbaugh S, Schott AM, Kressig RW et al. Vitamin $D$ and cognitive performance in adults: a systematic review. Eur J Neurol. 2009 Oct;16(10):1083-9. https://doi.org/10.1111/j.1468-1331.2009.02755.x

22. Keeney JT, Förster S, Sultana R, Brewer LD, Latimer $\mathrm{CS}$, Cai $\mathrm{J}$ et al. Dietary vitamin D deficiency in rats from middle to old age leads to elevated tyrosine nitration and proteomics changes in levels of key proteins in brain: implications for low vitamin D-dependent age-related cognitive decline. Free Radic Biol Med. 2013 Dec;65:324-34. https://doi.org/10.1016/j.freeradbiomed.2013.07.019

23. Briones TL, Darwish H. Vitamin D mitigates age-related cognitive decline through the modulation of pro-inflammatory state and decrease in amyloid burden. J Neuroinflammation. 2012 Oct;9(1):244. https://doi.org/10.1186/1742-2094-9-244

24. Mizwicki MT, Liu G, Fiala M, Magpantay L, Sayre J, Siani A et al. $1 \alpha, 25$-dihydroxyvitamin D3 and resolvin D1 retune the balance between amyloid- $\beta$ phagocytosis and inflammation in Alzheimer's disease patients. J Alzheimers Dis. 2013;34(1):155-70. https://doi.org/10.3233/JAD-121735

25. Cui X, Pelekanos M, Liu PY, Burne TH, McGrath JJ, Eyles DW. The vitamin D receptor in dopamine neurons; its presence in human substantia nigra and its ontogenesis in rat midbrain. Neuroscience. 2013 Apr;236:77-87. https://doi.org/10.1016/j.neuroscience.2013.01.035

26. Cui X, Pelekanos M, Burne TH, McGrath JJ, Eyles DW. Maternal vitamin D deficiency alters the expression of genes involved in dopamine specification in the developing rat mesencephalon. Neurosci Lett. 2010 Dec;486(3):220-3. https://doi.org/10.1016/j.neulet.2010.09.057

27. Kesby JP, Cui X, O'Loan J, McGrath JJ, Burne TH, Eyles DW. Developmental vitamin D deficiency alters dopamine-mediated behaviors and dopamine transporter function in adult female rats. Psychopharmacology (Berl). 2010 Jan;208(1):159-68. https://doi.org/10.1007/s00213-009-1717-y

28. Kesby JP, Cui X, Ko P, McGrath JJ, Burne TH, Eyles DW. Developmental vitamin D deficiency alters dopamine turnover in neonatal rat forebrain. Neurosci Lett. 2009 Sep;461(2):155-8. https://doi.org/10.1016/j.neulet.2009.05.070

29. Sutherland MK, Somerville MJ, Yoong LK, Bergeron C, Haussler MR, McLachlan DR. Reduction of vitamin D hormone receptor mRNA levels in Alzheimer as compared to Huntington hippocampus: correlation with calbindin-28k mRNA levels. Brain Res Mol Brain Res. 1992 Apr;13(3):239-50. https://doi.org/10.1016/0169-328X(92)90032-7

30. Annweiler C, Annweiler T, Bartha R, Herrmann FR, Camicioli R, Beauchet O. Vitamin D and white matter abnormalities in older adults: a cross-sectional neuroimaging study. Eur J Neurol. 2014 Dec;21(12):1436-e95. https://doi.org/10.1111/ene.12511

31. Hooshmand B, Lökk J, Solomon A, Mangialasche F, Miralbell J, Spulber G et al. Vitamin D in relation to cognitive impairment, cerebrospinal fluid biomarkers, and brain volumes. J Gerontol A Biol Sci Med Sci. 2014 Sep;69(9):1132-8. https://doi.org/10.1093/gerona/glu022

32. Annweiler C, Annweiler T, Montero-Odasso M, Bartha R, Beauchet $O$. Vitamin D and brain volumetric changes: systematic review and meta-analysis. Maturitas. 2014 May;78(1):30-9. https://doi.org/10.1016/j.maturitas.2014.02.013

33. Eyles DW, Burne TH, McGrath JJ D. Vitamin D, effects on brain development, adult brain function and the links between low levels of vitamin D and neuropsychiatric disease. Front Neuroendocrinol. 2013 Jan;34(1):47-64. https://doi.org/10.1016/j.yfrne.2012.07.001 